\title{
The Development of an SRSD-Based ESL Writing Instruction Module for Malaysian Secondary School Students.
}

\author{
Jacinta Karen Juin, Suyansah Swanto, Wardatul Akmam Din
}

To Link this Article: http://dx.doi.org/10.6007/IJARBSS/v11-i5/9216

DOI:10.6007/IJARBSS/v11-i5/9216

Received: 09 March 2021, Revised: 10 April 2021, Accepted: 30 April 2021

Published Online: 23 May 2021

In-Text Citation: (Juin et al., 2021)

To Cite this Article: Juin, J. K., Swanto, S., \& Din, W. A. (2021). The Development of an SRSD-Based ESL Writing Instruction Module for Malaysian Secondary School Students. International Journal of Academic Research in Business and Social Sciences, 11(5), 453-467.

\section{Copyright: (c) 2021 The Author(s)}

Published by Human Resource Management Academic Research Society (www.hrmars.com)

This article is published under the Creative Commons Attribution (CC BY 4.0) license. Anyone may reproduce, distribute, translate and create derivative works of this article (for both commercial and non-commercial purposes), subject to full attribution to the original publication and authors. The full terms of this license may be seen at: http://creativecommons.org/licences/by/4.0/legalcode

Vol. 11, No. 5, 2021, Pg. 453 - 467

Full Terms \& Conditions of access and use can be found at http://hrmars.com/index.php/pages/detail/publication-ethics 


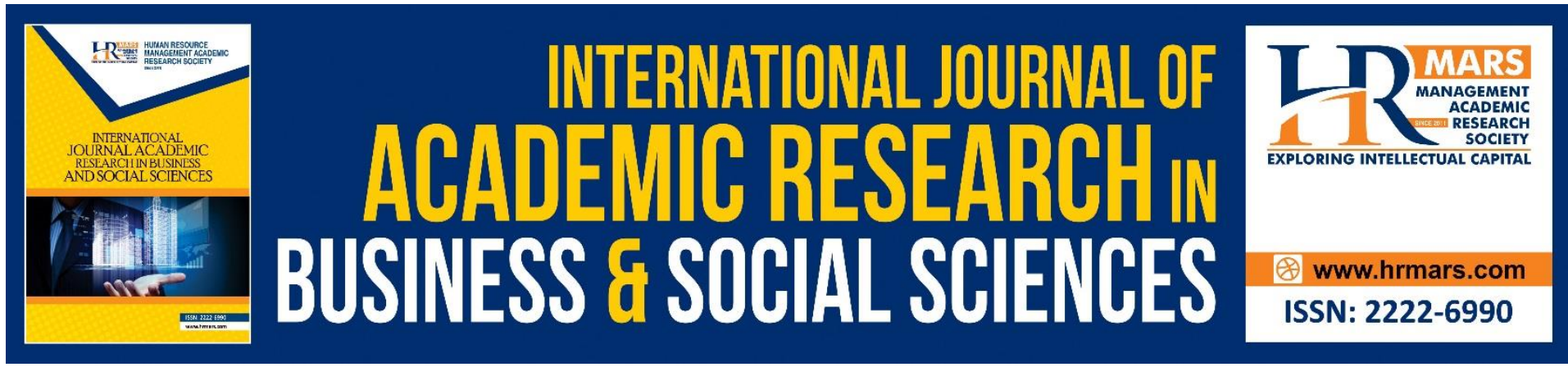

\title{
The Development of an SRSD-Based ESL Writing Instruction Module for Malaysian Secondary School Students.
}

\author{
Jacinta Karen Juin, Suyansah Swanto, Wardatul Akmam Din \\ Faculty of Psychology and Education, University Malaysia Sabah \\ Email: jacinta_juin@yahoo.com, suyansah@ums.edu.my,wardadin@ums.edu.my
}

\begin{abstract}
Writing has been known to be a demanding and difficult skill to teach and master in the ESL secondary school context. Writing intervention modules can be effective add-ons to existing writing lessons to help students who are struggling with writing to cope with the demands of this difficult skill. Despite many writing interventions developed, little has been explored on including self-regulation strategies explicitly into these interventions. The purpose of this paper is to discuss the development of a self-regulation strategies-based writing instruction module for secondary school students. The writing module adopted the Self-regulation Strategies Development model (SRSD) as its theoretical foundation and utilised a qualitative design through content analysis as data collection method. The six units writing instruction module was developed using the Kemp model as a design framework, including a need analysis, whereas the content validation was done through experts' panel evaluation. The results from the content validation suggest that the module can be used in the classroom to guide teachers to help them develop their students' self-regulation skills to help them cope with ESL writing. Future research suggestion includes testing the module's usability in real classrooms.
\end{abstract}

Keywords: SRSD, ESL Writing, Secondary School Students, Self-Regulation, Writing Module

\section{Introduction}

English is taught as a second language in Malaysia, and the writing skill is one of the four language skills being taught and tested in the classroom (Tan and Miller, 2007; Swanto et al., 2010; Swanto et al., 2014; Suppiah et al., 2019). Writing is an essential skill that is considered as a highly complex task which requires the writer to use different number of skills at the same time (Harris et al., 2002; Parilah et al., 2011; Swanto et al., 2010; Swanto et al., 2014; Suppiah et al., 2019). Writing also requires extensive self-regulation and attentional control (Graham \& Harris, 1997). The teaching and learning of ESL writing skill can be complex (Vengadasamy, 2006) and writing instruction is often perceived as an intimidating task for many teachers (Maarof, Yamat, \& Kee, 2011; Swanto et al., 2010; Swanto et al., 2014; Suppiah et al., 2019).

There are many concerns related to Malaysian secondary school students' declining writing performance. In most Malaysian classrooms, previous studies found that a lot of teachers 
complain that their students have hesitation when attempting writing tasks due to their perception that writing in English is difficult and would often leave their writing half done due to their lack of language skills (Mastan, Maarof, \& Embi, 2017; Shah et al., 2011). Writing creates apprehension among ESL students (Akhtar, Hassan, \& Saidalvi, 2020) therefore causing efforts to compose a piece of quality essay to be laborious and stressful for secondary school students. Students, especially those who possess limited English proficiency, would often produce written work that is brief, difficult to read, plagiarised from peers and most of the time, incomplete or not attempted at all (Pajares, 2002).

Teachers have designed and tested the latest methods, models, and relevant practices in their effort to make writing easier for their students and improve students' writing performance (Malpique and Simão, 2015). In the Malaysian context, however, it can be observed that most writing intervention modules are often aimed at improving secondary students' writing performances, especially in helping struggling or limited English proficiency students to score well. Besides, these modules are mostly targeted towards students who are sitting for national examinations. Most teachers developed their own writing intervention modules to help struggling students with techniques of answering examination questions, on language elements such as grammar and vocabulary, including providing tips for scoring well in their examination. Exercises in these modules often focused on intense practice essays or "drilling" based on popular examination topics. Despite the extensive essay writing exercises and focus on increasing students' writing scores, this approach is only effective for the short term and could be less sustainable for students' mastery of the writing skill in the long term. Existing writing modules seemed to be catered for examination purposes and due to this nature, it may hinder students' potential to be responsible for their learning process.

Although existing writing modules are generally helpful in improving students' grades for the writing component, less attention was given to improving students' attempts towards initiating and regulating their efforts to improve their writing skills. Secondary school students may possess a certain level of self-regulation, but the extent of their self-regulation could be negative or underdeveloped (Zimmerman, Bonner, \& Kovach, 1996). Students' lack of capacity to self-regulate could be attributed to the lack of guidance on how to effectively use their self-regulation capacity, and one of the approaches to do so is to teach the students how to regulate self-regulation strategies use.

Writing requires the writer to engage in various inner processes, such as thinking of an idea, connecting them as well as managing and planning to ensure that what started as a sentence, eventually forms a piece of coherent writing. These processes are often undertaken individually and may require a certain degree of self-regulation to persevere. Writing is fundamentally a cognitive process; however, theorists of writing believe that writing involves more than just the cognitive process, it also involves planning, motivation, and consideration of readers through the social context. Harris, Graham, and Mason (2017) posited that skilled writing is a complex and intricate process as writers would face affective, cognitive, or metacognitive, and behavioural challenges - and such complexity requires high selfregulation skills from the writer's part. Writers also need to consider and negotiate writing rules and their mechanisms while attempting to maintain a focus on the over-all organization, form and features, purposes and goals, and audience needs and perspectives (Harris et al., 2002). As Flower and Hayes (1981) observed, "a great part of the skill in writing is the ability 
to monitor and direct one's own composing processes". Writing has been proven to be complex, hence a writer must be able to self-regulate this intricate process. Based on these observations, this paper proposed to develop a writing instruction module that employs a self-regulation strategies approach towards improving secondary school students' writing performance.

\section{Self-Regulated Strategy Development model}

Writing intervention modules could perhaps be more effective and sustainable if students can self-regulate their own learning using appropriate writing and self-regulation strategies. Previous studies have suggested the use of the Self-Regulation Strategies Development model or SRSD, developed by Karen Harris in 1982 (Graham \& Harris, 2018) to help students to improve their writing performance as well as to develop their self-regulatory skills. Therefore this model could be used as an instructional strategy to integrate teaching writing approach and teaching the self-regulation strategies as SRSD is an approach used to instruct students on applying specific strategies for carrying out composing processes such as planning, drafting, and revising (Graham \& Harris, 2018). SRSD is also an effective method for teaching writing strategies to all students, regardless of their writing ability including struggling writers and students with varying disabilities (Harris \& Graham, 2016; Saddler \& Andrade, 2004).

The SRSD model was designed to address the complex nature of writing and the difficulties that most students of all ages experience in their effort of learning to write as well as in dealing with the affective, cognitive, and behavioural requirements that writing imposes (McKeown et al., 2016). The SRSD model is a validated model which has been used by various educational context to improve the level of writing among learners who were diagnosed with learning difficulties (Liberty \& Conderman, 2018; Pajares, 2002; Santangelo, Harris, \& Graham, 2008). One of the main goals of SRSD includes embedding self- regulation procedures (for example, self-instructions, goal setting, self-monitoring, and selfreinforcement) within strategy development, to ensure students' use of strategies to be "automatic, routine, and flexible" (Harris et al., 2002).

There are six stages in the SRSD model namely develop background knowledge, discuss the strategy, model the strategy, memorize the strategy, support the strategy and independent work. The six stages in this model are recursive and can be repeated at any part of the lessons. In the first stage, develop background knowledge, the teacher identifies their students' skills deficits and proceeds to help them develop background skills that they needed to understand, learn, and apply the strategy. In the second stage, which is discuss the strategy, both teacher and students discuss about the students' performance to find areas that they wanted to improve on and discuss how to monitor their progress. At this stage, the teacher also introduces the strategy and perhaps use a mnemonic device for the students to remember the strategy taught.

The third stage, which is model the strategy involves the teacher modelling the target strategy as many times as necessary, for example by using think-aloud strategy or simply modelling it step-by-step. Goal-setting strategies may also be introduced at this point of the stage or at any stage that the teacher deemed appropriate. The next stage is to memorize the strategy. This is where the students use mnemonic devices or any other memorizing techniques to remember the strategy they learned. The fifth stage of SRSD is supporting the strategy where students gradually assume the responsibility for applying the strategy. The teacher gradually weans support by allowing space for the students to apply the strategy but still be present to 
provide support according to the students' needs. The teacher also provides constructive feedbacks and offer students positive reinforcements through words of affirmation. Finally, the sixth stage of the model, the independent work, requires the students to apply and practice the strategies they have learned in the skill (Helsel \& Greenberg, 2007).

Informed by previous studies and existing literatures on writing, self-regulation, and SRSD model, the researcher reasoned that integrating the SRSD model into each of the five stages of the process writing approach would help teachers to teach explicitly relevant selfregulation strategies such as setting goals and managing task before the planning stage, drafting their essay using templates and teaching students how to organise their ideas, using mnemonics or memorising techniques to remember and recall editing and revising strategies, and sustain the students' motivation by self-talk or self-affirmation until the publishing stage. The module is tentatively called the SRSD-Based Writing Intervention Module. The term intervention in this paper is operationally defined as a writing instruction module as it is an instructional package that relates to a certain unit or concept and it comprises of complete teaching and learning package relevant to the unit or concept being taught (Russell, 1974, as cited in Noah \& Ahmad, 2005; Husen \& Postlethwaite, 1985). Other reasons for calling the intervention as a "module" were justified by the nature of the intervention. Firstly, the module instructional aspect is focused on teachers guiding their students to foster selfregulation skills using the writing skill by teaching them how to apply self-regulation strategies when dealing with their assigned writing tasks. Secondly, the teacher acts as the facilitator as they are the ones who will administer the module units to the students and facilitate the implementation of the module in their classroom.

Therefore, the purpose of this paper is to describe the development and expert's validation processes of the proposed self-regulation strategies-based writing instruction module. The questions that guided the design and development processes described in this paper are as follows:

1. How does the SRSD model be applied in the development of a self-regulation strategies-based writing module for secondary school students?

2. What is the outcome of the experts' evaluation of the module?

\section{Methodology}

Study Design

This study was part of a larger project using a three phases design and development research design (Richey \& Klein, 2005). This paper reports the second phase of this study, which comprised of two processes, namely the module's design and development and the expert's evaluation.

\section{Measures}

This study adapted the Kemp model as the design framework for the writing module. The justification for using the Kemp model is because it is an integrated and comprehensive model that possess non-linear, learner-oriented yet systematic and specific steps in developing a module (Akbulut, 2007; Kurt, 2016). Based on the Kemp model of instructional design, there are nine components which were expanded from the four fundamentals of instructional design: learners, objectives, methods, and evaluation. The nine components comprise of identifying instructional problems, learners, and context; task analysis, determining instructional objectives, content sequencing, instructional strategies, designing the message, 
development of instruction, and designing evaluation instruments - and these elements require thoughtful consideration when building a module. After identifying the need for a writing intervention, determining the aims, learning outcomes, and content of the module, the module's pages and materials were combined into a draft. The draft will then go through the validation phase.

A content analysis was done on secondary school English subject curriculum and syllabus to determine the learning outcomes for the module. Textbooks, English subject workbooks, and teaching and learning materials such as worksheets and graphic organisers were carefully selected to ensure that the module adheres to the requirements of the syllabus. Two selfregulation related learning objectives i.e task analysis and goal-setting were added to the module's learning outcome.

For the content validity assessment process, the content validation was assessed by a panel of evaluators who are experts in the English language subject and experienced teachers. The process of the content validity assessment is as follows. Firstly, the researcher submitted a draft of the writing module and a 5 items validation protocol to each evaluator. The protocol is based on the recommendations by Russell (1974 in Sidek Noah and Ahmad, 2005)) regarding the five conditions of module validity. The validation protocol covers the criteria suggested which includes the suitability of the module to the target population, the time spent on the module and whether the module would increase the students' achievement levels and improve the students' attitude towards writing.

\section{Participants}

For expert evaluation, three experienced English subject teachers who possess more than 10 years' experience of teaching the English subject in secondary school and two SISC+ were requested to evaluate the content validity. Three teachers consist of CEFR master trainers and are experienced in evaluating textbooks and modules. The teachers selected were also English language subject examiners for national examinations, namely Pentaksiran Tingkatan 3 (PT3) and Sijil Pelajaran Malaysia (SPM). Three evaluators possess a Masters in TESL degree.

\section{Findings}

This section reports the findings of the design and development phase. This section describes the module development process and the expert's validation outcome.

\section{Phases of Module Development}

Identifying instructional problem and learners' characteristics

The design and development process for this module began with identifying the characteristics, context and needs of the learners through the need analysis. The need analysis corresponded with the first and second elements of the Kemp model, in which it required the developer to identify the instructional problem and the learners' characteristics. The needs analysis study was conducted in a separate study (Juin, Swanto, \& Din, 2021) via semi-structured single focus group interviews with seven English language secondary school teachers and the findings from the needs' analysis phase revealed that the participants observed behavioural aspects of their students that suggest a lack of self-regulation skill, for example procrastination and reluctance to ask for help, when attempting and completing writing tasks. Teachers also reported that despite using a learner-centred approach when 
teaching the writing skills, students still unaware and find it difficult to regulate writing strategies such as planning. The outcome for the needs research confirmed the need to have an intervention or instructional module that could serve to improve students' writing performance and to help them develop self-regulation skills. In addition to the needs' analysis study, an extensive search of the literature review was also conducted on existing writing intervention or programmes for Malaysian secondary school students and in the international platform to identify the gaps needed to be addressed in the writing module.

\section{Module Components and Contents}

After the learners' needs and characteristics were identified, the content knowledge and procedures to include in the module were defined through an analytical selection of existing writing materials found in workbooks, textbooks, and online resources. Using a content analysis approach, the materials for the contents were selected based on their relevance to the learning outcome provided by the English language subject secondary school curriculum. This module's components consist of four parts:

Table 1: Module Components

\begin{tabular}{|c|c|c|}
\hline No & Component & Descriptions \\
\hline 1 & Introduction to the module & $\begin{array}{l}\text { This component introduces the module and outlined } \\
\text { the module's purpose, objectives, target users, and } \\
\text { the structure of the module. }\end{array}$ \\
\hline 2 & Teacher's guide & $\begin{array}{l}\text { Labelled as "Read this first", this two-parts brief } \\
\text { section guides teachers on how to use and adapt the } \\
\text { module in their lessons. The first part consists of the } \\
\text { elements involved in the module, for example the } \\
\text { strategies and the instructional strategy adopted in } \\
\text { the model. It described the SRSD model to teachers, } \\
\text { self-regulation strategies that teachers can utilise in } \\
\text { the classroom, suggestions on how to model the } \\
\text { strategies to students and finally, additional writing } \\
\text { strategies that teachers can adopt into their lesson. } \\
\text { The second part comprise of the instruction for } \\
\text { teachers on how to use the module in their } \\
\text { classroom. The assessment guideline for assessing } \\
\text { unit mastery is also included at the end of the } \\
\text { component. }\end{array}$ \\
\hline 3 & Unit Activities & $\begin{array}{l}\text { There are six units in this section. It includes the } \\
\text { rationale of the respective unit, the learning } \\
\text { outcome, the procedure, learning activities, and } \\
\text { suggestion for variation. Each unit also include } \\
\text { assessment questions and a 5-point students' unit } \\
\text { mastery scale. }\end{array}$ \\
\hline 4 & Pre-Post Assessment Test & $\begin{array}{l}\text { This component comprises of writing tasks that } \\
\text { teachers can use to assess their students' } \\
\text { performance before and after the module was used } \\
\text { in the classroom. }\end{array}$ \\
\hline
\end{tabular}


After the learning outcomes, topic and materials were selected, the six units in this module were arranged according to the five stages of the process writing approach. As an instructional strategy, the six stages of SRSD were embedded in each module unit, following the example from Sexton, Harris, \& Graham (1998, p.299-301) study. An example of how the phases in the SRSD model were embedded can be seen in Appendix 1.

The module units started with a task analysis activity, followed by a goal-setting exercise where teachers can guide students to set targets for the writing task. The module units then progress to the planning unit, where students will be guided to use planning strategies before writing. After the planning unit, students are then guided on how to write their first drafts using drafting strategies, for example a paragraph model. Students then practice the use of writing strategies to edit and revise their draft. The teacher supports the students as they practice through gradual scaffolding and may repeat the stages of both SRSD and process writing approach until students achieve the success criteria of the writing phase.

Table 2: Module Units' Descriptions

\begin{tabular}{|c|c|c|}
\hline Units & Objective & Activity \\
\hline $\begin{array}{l}\text { 1. Task } \\
\text { Analysis }\end{array}$ & $\begin{array}{l}\text { At the end of this unit, students } \\
\text { should be able to have relevant } \\
\text { background knowledge regarding the } \\
\text { target essay by learning how to } \\
\text { analyse a text and analysing the } \\
\text { writing task. }\end{array}$ & $\begin{array}{l}\text { 1. Wreck-A-Text } \\
\text { 2. Wreck-A-Task }\end{array}$ \\
\hline 2. Goal-setting & $\begin{array}{l}\text { At the end of this unit, students } \\
\text { should be able to set goals and plan } \\
\text { how they can achieve their writing } \\
\text { goal. }\end{array}$ & $\begin{array}{l}\text { 1. SMART goals } \\
\text { 2. My Writing Goals }\end{array}$ \\
\hline 3. Planning & $\begin{array}{l}\text { At the end of this unit, students } \\
\text { should be able to use various } \\
\text { planning strategies such as mind- } \\
\text { mapping. }\end{array}$ & $\begin{array}{l}\text { 1. Four square method } \\
\text { 2. Mind-mapping } \\
\text { 3. Outlining }\end{array}$ \\
\hline 4. Drafting & $\begin{array}{l}\text { At the end of this unit, students } \\
\text { should be able to draft their essay } \\
\text { using drafting strategies. }\end{array}$ & 1. Paragraph model \\
\hline $\begin{array}{l}\text { 5. Editing and } \\
\text { Revising }\end{array}$ & $\begin{array}{l}\text { At the end of this unit, students } \\
\text { should be able edit and revise using } \\
\text { the mnemonics such as ARMS and } \\
\text { CUPS. }\end{array}$ & $\begin{array}{l}\text { 1. Use ARMS strategy } \\
\text { for editing } \\
\text { 2. Use COPS strategy } \\
\text { for revising } \\
\text { 3. Checklist for editing } \\
\text { and revising }\end{array}$ \\
\hline $\begin{array}{l}\text { 6. Independent } \\
\text { work }\end{array}$ & $\begin{array}{l}\text { At the end of this unit, students } \\
\text { should be able to write their essay } \\
\text { independently with no or little help } \\
\text { from the teacher. }\end{array}$ & 1. Strategy use practice \\
\hline
\end{tabular}

In addition to the writing lesson materials, the researcher added self-regulation strategies that teachers may teach to their students, for example, goal-setting. The contents of each 
components were also ensured that they follow a logical presentation and sequence by following the process writing model.

The contents for this module consist of lesson plan units and supporting materials that teachers can use to guide their activities based on Objective-Instruction-Assessment suggested by (Sullivan, Ice, \& Niedermeyer, 2000). Teachers were also given the liberty to select appropriate writing topic or tasks for their students based on the units as to provide teachers with the autonomy of selecting suitable writing tasks or materials that is appropriate for their students. The activity materials such as a goal-setting worksheet and an editing/revising checklist were designed and prepared for this module, however teachers may also adapt the materials to fit their own classroom needs and teaching styles, provided that the SRSD model stages were utilised when conveying the content and materials. The graphic organisers and the self-regulation strategies worksheets in the module were adapted and designed using attractive typography to gauge students' interest.

For assessment, the researcher used performance-based assessment where at the end of the module, students would be given a writing test to assess their writing performance before and after the module was administered.

\section{Content Validity results}

The module was validated by five subject-matter experts which comprised of senior English teachers who possess vast experience in evaluating textbooks and learning modules; are teacher trainers, and have been teaching the English language subject in secondary schools for at least ten years and above.

Prior to modifying the module as per experts' recommendation, the raters' agreement will be calculated using Tuckman and Waheed (1981 as cited in Noah and Ahmad, 2005) and Abu Bakar Nordin's (1995) percentage recommendation. According to them, if the rater's percentage is $70 \%$ and above, the module's content validity is considered as good and acceptable content validity. The formula for calculating the percentage can be seen below:

Rater's scores $(x)$

Maximum Score (25)

$$
X 100 \%=\text { Content Validity Percentage }
$$

The results and comments of the experts' evaluation are as follows:

Table 3: Validity Index of Writing Module Expert Panels

\begin{tabular}{|l|l|l|}
\hline Expert & $\begin{array}{l}\text { Percentage } \\
(\mathbf{1 0 0 \% )}\end{array}$ & $\begin{array}{l}\text { Score } \\
\mathbf{( 2 5 )}\end{array}$ \\
\hline Expert Panel I & 76 & 19 \\
\hline Expert Panel II & 96 & 24 \\
\hline Expert Panel III & 76 & 19 \\
\hline Expert Panel IV & 96 & 24 \\
\hline Expert Panel V & 72 & 18 \\
\hline \multicolumn{2}{|l|}{ Total of Average: 0.83 } &
\end{tabular}


The experts' comments and suggestions were summed up as follows (Table 4):

Table 4: Summary of Experts' Comments and Suggestions

\begin{tabular}{|l|l|}
\hline Expert & Comments and Suggestion \\
\hline Expert Panel I & $\begin{array}{l}\text { A doable module for the classroom. } \\
\text { Time could be an issue for teachers. }\end{array}$ \\
\hline Expert Panel II & $\begin{array}{l}\text { Teachers can adapt the module accordingly which encourages } \\
\text { flexibility to suit students' and teachers' needs. } \\
\text { Clear step-by-step guide for users on how to use the module. Examples } \\
\text { were also given as reference. As for the time stipulated, teachers may } \\
\text { need to extend the length as they must rearrange their yearly scheme } \\
\text { of work to cover for the lost contact hours due to Covid-19. }\end{array}$ \\
\hline Expert Panel III & $\begin{array}{l}\text { For students with limited English proficiency (extremely weak/low } \\
\text { proficiency), they need more time because they lack motivation to } \\
\text { write. } \\
\text { The module can be used for students of different levels of proficiency } \\
\text { or different forms. }\end{array}$ \\
\hline Expert Panel IV & $\begin{array}{l}\text { The module is suitable and appropriate. It is a great module to assist } \\
\text { the teachers. }\end{array}$ \\
\hline Expert Panel V & $\begin{array}{l}\text { This module is feasible depending on your target students. This } \\
\text { module could help students to achieve the ability to communicate } \\
\text { effectively as it allows them to link up the four basic skills (speaking, } \\
\text { reading, writing, and listening) even though it is originally meant for } \\
\text { writing skills. }\end{array}$ \\
\hline
\end{tabular}

Based on the findings above, it can be assumed that the content validity of the module is good. Suggestions from the panels, especially on the issue of timing was addressed by the researcher by omitting redundant writing strategies and by creating a criterion table for teachers as a guide for moving on to the next unit. After receiving the experts' feedback, the researcher made the necessary changes or improvements recommended.

\section{Discussion}

In the design and development process, the Kemp model has been a useful design framework to apply the SRSD model in developing the self-regulation strategies-based writing module. The nine elements of the Kemp model were adapted into the design and development process. The SRSD model was utilised as an instructional strategy and integrated into the process writing approach through a systematic development process, by identifying the needs for the module, determining learning outcomes, and selecting suitable contents, materials, and assessment tools.

The findings implied that based on experts' evaluation on the contents of the module, the SRSD-based writing instruction module has good content validity score and after some revisions and adjustments, it is ready to be used for the classroom. The SRSD-based writing module was developed in lieu with the requirements of the Malaysian secondary school English language syllabus. The module's content validity shows that the content of the module is appropriate for English subject writing skills for secondary school students, particularly for students who often struggles with writing. Experts who validated the module also agreed that the module's content can be used in the classroom and help students to develop self-regulation skills to help them cope with the demands of writing. Timing issue was 
brought up by the panel and the researcher addressed the issue by omitting redundant activities and by creating a criterion table for teachers to guide them in assessing the students' readiness to progress to the next unit. All experts agreed that the module is suitable for the target participants and could be implemented in the classroom.

The implication from the development and validation of this module is that teachers who deal with struggling writers will be able to help their students use strategies and provide the students with independent skills that could help them when writing independently. Based on the findings, it may be concluded that the module may now be used in an actual study, and its effectiveness could be tested in actual secondary school classrooms. Future undertakings for this module would be to test its usability in actual secondary school classrooms and to explore the impacts of a self-regulation strategies-based module may have on the writing performance of secondary school students.

\section{Conclusion}

The SRSD-based writing module was developed due to the needs of having a writing programme or intervention that could guide teachers to help their students to be selfregulated through the development of self-regulation skills. The major findings in this paper comprised of how the six stages of the SRSD model were applied into the design and development process of an ESL writing instruction module for secondary school students, and how the module was validated by a panel of experts. The SRSD model was applied into the writing module using the KEMP model as a design framework. The nine steps of the KEMP model helped framed the selection of learning materials up to the content sequencing and the assessment for students. The experts validated the module and given the model 0.83 content validity score, indicating that the experts agreed that the module has good reliability score. In conclusion, this paper discussed and demonstrated how a writing intervention module was developed and validated by experts in order to determine its validity and usability for the intended participants with hope that it can be potentially used to help secondary school students cope with the demands of mastering the writing skill. Future undertakings regarding this SRSD-based writing instruction module could include testing the module in actual secondary school classrooms.

\section{References}

Abu Bakar, N. (1995). Penilaian Afektif. Kajang: Masa Enterprise

Akbulut, Y. (2007). Implications of two well-known models for instructional designers in distance education: Dick-carey versus Morrison-ross-kemp. Turkish Online Journal of Distance Education, 8(2), 62-68. https://doi.org/10.17718/tojde.13470

Akhtar, R., Hassan, H., \& Saidalvi, A. (2020). The effects of ESL student"s attitude on academic writing apprehensions and academic writing challenges. International Journal of Psychosocial Rehabilitation, 24(5), 5404-5412. https://doi.org/10.37200/IJPR/V24I5/PR2020247

Flower, L., \& Hayes, J. R. (1981). A Cognitive Process Theory of Writing. College Composition and Communication, 32(4), 365. https://doi.org/10.2307/356600

Graham, S., \& Harris, K. R. (1997). Self-Regulation and Writing: Where Do We Go from Here? Contemporary Educational Psychology, 22(1), 102-114. https://doi.org/10.1006/ceps.1997.0920

Graham, S., \& Harris, K. R. (2018). An examination of the design principles underlying a selfregulated strategy development study. Journal of Writing Research, 10(2), 139-187. 
https://doi.org/10.17239/jowr-2018.10.02.02

Harris, K. R., \& Graham, S. (2016). Self-Regulated Strategy Development in Writing: Policy Implications of an Evidence-Based Practice. Policy Insights from the Behavioral and Brain Sciences, 3(1), 77-84. https://doi.org/10.1177/2372732215624216

Harris, K. R., Graham, S., \& Mason, L. H. (2017). Self-Regulated Strategy Development in the Classroom: Part of a Balanced Approach to Writing Instruction for Students With Disabilities. Focus on Exceptional Children, 35(7). https://doi.org/10.17161/foec.v35i7.6799

Harris, K. R., Mason, L. H., Graham, S., \& Saddler, B. (2002). Developing Self-Regulated Writers. Theory Into Practice, 41(2), 110-115.

Helsel, L., \& Greenberg, D. (2007). Helping struggling writers succeed: A self-regulated strategy instruction program. https://doi.org/10.1598/RT.60.8.5

Juin, J. K., Swanto, S., \& Din, W. A. (2021). Characteristics and Teaching Challenges of Struggling Secondary School Writers : Assessing the need for self-regulation strategies based instruction. Journal of Educational Research and Indigenous Studies, 3(1), 13-22.

Kurt, S. (2016). Kemp Design Model. Retrieved July 22, 2020, from https://educationaltechnology.net/kemp-design-model/

Liberty, L. M., \& Conderman, G. (2018). Using the Self-regulated Strategy Development Model to Support Middle-level Writing. The Clearing House: A Journal of Educational Strategies, Issues and Ideas, 0(0), 1-6. https://doi.org/10.1080/00098655.2018.1426303

Malpique, A. A., \& Simão, M. V. A. (2015). Assessing Self-Regulated Strategies for School Writing: Cross-Cultural Validation of a Triadic Measure. Journal of Psychoeducational Assessment, 33(2), 141-153. https://doi.org/10.1177/0734282914547873

Mastan, M. E., Maarof, N., \& Embi, M. A. (2017). The effect of writing strategy instruction on ESL intermediate proficiency learners ' writing performance. Journal of Educational Research and Review, 5(5), 71-78.

McKeown, D., Brindle, M., Harris, K. R., Graham, S., Collins, A. A., \& Brown, M. (2016). Illuminating growth and struggles using mixed methods: Practice-based professional development and coaching for differentiating SRSD instruction in writing. Reading and Writing, 29(6), 1105-1140. https://doi.org/10.1007/s11145-016-9627-y

Noah, S. M., \& Ahmad, J. (2005). Pembinaan Modul: Bagaimana Membina Modul Latihan dan Modul Akademik. (1st ed.). Serdang: Penerbit Universiti Putra Malaysia.

Pajares, F. (2002). Becoming a Self-Regulated Learner: An OverviewN. Theory into Practice, 41(2), 64-67. https://doi.org/10.1207/s15430421tip4102

Richey, R. C., \& Klein, J. D. (2005). Developmental research methods: Creating knowledge from instructional design and development practice. Journal of Computing in Higher Education, 16(2), 23-38. https://doi.org/10.1007/BF02961473

Saddler, B., \& Andrade, H. (2004). The Writing Rubric Instructional rubrics can help students become self-regulated writers (Vol. 62).

Santangelo, T., Harris, K. R., \& Graham, S. (2008). Using Self-Regulated Strategy Development to Support Students Who Have "Trubol Giting Thangs Into Werds." Remedial and Special Education, 29(2), 78-89. https://doi.org/10.1177/0741932507311636

Sexton, M., Harris, K. R., \& Graham, S. (1998). Self-Regulated Strategy Development and the Writing Process: Effects on Essay Writing and Attributions. Exceptional Children, 64(3), 295-311. https://doi.org/10.1177/001440299806400301 
Shah, P. M., Hamiah, W., Mahmud, W., Din, R., Yusof, A., \& Pardi, K. M. (2011). Self-Efficacy in the Writing of Malaysian ESL Learners. World Applied Sciences Journal, 15(Innovation and Pedagogy for Lifelong Learning), 8-11.

Sullivan, H., Ice, K., \& Niedermeyer, F. (2000). Long-term instructional development: A 20year ID and implementation project. Educational Technology Research and Development, 48(4), 87-99. https://doi.org/10.1007/BF02300501

Tan, K. E., \& Miller, J. (2007). Writing in English in Malaysian high schools: The discourse of examinations. Language and Education, 21(2), 124-140. https://doi.org/10.2167/le663.0

Zimmerman, B. J., Bonner, S., \& Kovach, R. (1996). Developing Self-Regulated Learners. Focus on Exceptional Children. Retrieved from http://library.lol/main/94C88724B8BFD5A735567B5972FCC8EF 


\section{Appendix A: Sample Module Unit and Activity Sheet}

\section{Unit 2}

\section{Goal-setting \& Task Planning}

Rationale: Part of the self-regulation strategies for writing is to encourage students to set a target before embarking on a writing task. Setting an achievable goal could help the students to be aware of the task and work towards achieving their goal.

\begin{tabular}{|c|c|}
\hline Objective(s) & $\begin{array}{l}\text { At the end of the session, students should be able to } \\
\text { (i) set at least } 3 \text { achievable targets for their essay writing } \\
\text { (ii) provide } 3 \text { or more actions on how to achieve their goals }\end{array}$ \\
\hline Purpose & $\begin{array}{l}\text { Setting goals } \\
\text { Planning for a task }\end{array}$ \\
\hline $\begin{array}{l}\text { Learning } \\
\text { Outcome }\end{array}$ & $\begin{array}{l}\text { 4.1. Communicate intelligibly through print and digital media on } \\
\text { familiar topics. } \\
\text { 4.2. Communicate with appropriate language, form and style. }\end{array}$ \\
\hline Activity & My Essay Resolution \\
\hline Time & Approximately 20 to 30 minutes \\
\hline $\begin{array}{l}\text { Suggested } \\
\text { Materials/ } \\
\text { teaching aids }\end{array}$ & $\begin{array}{l}\text { Target Worksheet (refer next page, SMART and simpler version is also } \\
\text { available), whiteboard, markers }\end{array}$ \\
\hline How to & $\begin{array}{l}\text { Whole class discussion } \\
\text { Modelling }\end{array}$ \\
\hline
\end{tabular}

\begin{tabular}{|l|l|}
\hline \multicolumn{2}{|c|}{ Procedures and Strategies } \\
\hline Activity/Procedure & Strategy/Approaches \\
\hline 1. Teacher begins the lesson by bringing & SRSD: Goal-setting \\
students into discussion about setting & Strategy: SMART goals \\
goals for their essay. Get students to & \\
talk and share about how they think & \\
they could improve their essay or & \\
writing skills. \\
2. Students discuss with teacher what they & \\
wanted to achieve by the end of the & \\
writing lessons. Get students to share & \\
about how they plan to achieve their & \\
target(s), teacher can help out by & \\
providing tips on how they could plan & \\
and achieve their target. & \\
3. Teacher informs students to fill in the & Pair work/Individual \\
provided worksheet. Teacher can use & \\
Writing Intervention Goals Worksheet & \\
(page 28) for a detailed plan or SMART & \\
Goal Worksheet (page 30) for a simpler, & \\
one-task goal. Each student will get a & \\
goal setting worksheet. &
\end{tabular}


4. Students fill in the worksheet, they can discuss with a partner or do it individually.

5. Throughout the stages, always bring back students to their goals and have them assess their progress. The goals or self-statements that they have written may be altered to suit their level.

\section{Variation}

1. Ask students to paste their goal worksheet in their exercise book. This could encourage them to continuously check on their progress and be accountable for it. It is also useful for the reflection session at the end of the unit.

2. If possible, have a whole class goal for the current writing task. The goals could relate to the writing process - something the whole class can achieve together. Write the classroom goal on the whiteboard or on a portable whiteboard (easy to hang and would not be lost!). Have a celebration or a treat once the classroom goals have been achieved e.g. Song Day, Games Day, etc.

\section{Assessment}

Students were able to fill in realistic targets in the Target Worksheet.

Assessment questions:

Are the students' goals specific and measurable?

Is there a time stipulated in the students' goals?

Can the students carry out the plan to achieve their goals?

\section{Students' Unit Mastery Level}

\begin{tabular}{|c|c|c|c|c|}
\hline $\mathbf{1}$ & $\mathbf{2}$ & $\mathbf{3}$ & $\mathbf{4}$ & $\mathbf{5}$ \\
\hline Poor mastery & Weak mastery & Neutral & Good mastery & Strong mastery \\
\hline \multicolumn{5}{|c|}{ Teacher's Notes }
\end{tabular}

